\title{
Glucose-6-phosphate dehydrogenase deficiency and chronic haemolysis in an English family
}

\author{
E. C. HUSKISSON, B. MURPHY, AND CAROLYN WEST \\ From St Stephen's Hospital and the Department of Clinical Haematology, University College \\ Hospital Medical School, London
}

SYNOPSIS Three male members of an English family with chronic haemoiytic anaemia due to
glucose-6-phosphate dehydrogenase deficiency are reported. The disease was symptomless in
one adult, but crises, caused either by increased haemolysis or failure of marrow compensation,
occurred in two children. They were typically precipitated by trivial infection. Two normal
female members of the family were obligatory heterozygotes. A hitherto undescribed 'slow'
variant of the enzyme was identified electrophoretically.

The association of acute or chronic haemolysis and reduced levels of glucose-6-phosphate dehydrogenase (G6PD) in the red cell is well known, and a wide range of disorders resulting from it is recognized throughout the world (Carson and Frischer, 1966). Different clinical manifestations are associated with molecular variants of the enzyme, identifiable electrophoretically or by other characteristics. Acute haemolysis was first described following the introduction of the 8-aminoquinoline antimalarials but many other drugs, infections, and broad beans (favism) can precipitate haemolysis in susceptible subjects. Transfusion studies showed that the tendency to haemolysis was a peculiarity of the red cells of the affected individual, and this peculiarity was later identified as deficiency of the enzyme G6PD, genetically determined and transmitted as a sex-linked intermediate character.

Very low levels of G6PD have been described in a small number of families, mostly of western European origin, associated with chronic haemolytic anaemia. A compensated haemolytic state beginning at birth is interrupted by crises of increased haemolysis associated with infection or drugs.

The exact incidence of G6PD deficiency in England is not known, but is probably very low.

${ }^{1}$ Correspondence should be addressed to Dr E. C. Huskisson at Westminster Hospital, London SW1.

Received for publication 6 February 1969.
Shortage of susceptible subjects and the un- $\stackrel{\mathbb{Q}}{\mathscr{Q}}$ common occasion for the use of antimalarial $\overrightarrow{\vec{B}}$ drugs have made primaquine sensitivity a $\stackrel{\circ}{3}$ rarity, largely confined to immigrants. Three English families have been reported in whom favism was the only manifestation of G6PD deficiency (Davies, 1962; Brodribb and Wors-? sam, 1961). In two English families, chronic haemolytic anaemia has been found to be associated with this deficiency (Blackburn and $\frac{\mathrm{O}}{3}$ Lorber, 1963; Bowdler and Prankerd, 1964). We report a further family in whom an electrophoretically distinct enzyme variant was identi- $\frac{D}{2}$ fied.

\section{Case Reports}

\section{CASE III 5}

A boy, of English descent, presented in October $\stackrel{\overparen{D}}{\stackrel{Q}{\hookrightarrow}}$ 1965 , aged 12, with severe anaemia of acute $?$ onset. There was a vague history of preceding upper respiratory tract infection treated with $\vec{D}$ penicillin. He was admitted with complaints of $\frac{\rho}{\mathbb{Q}}$ headache, tiredness, and dizziness, and on $\varrho$ examination was very pale and febrile $\left(102^{\circ} \mathrm{F}\right)$. The spleen was not palpable. Laboratory 8 investigations gave the following results: haemoglobin level $5.6 \mathrm{~g} / 100 \mathrm{ml}$, packed cell volume $16 \%$, and normal red cell morphology; a white blood count of $5,600 / \mathrm{c} \mathrm{mm}$ with a 


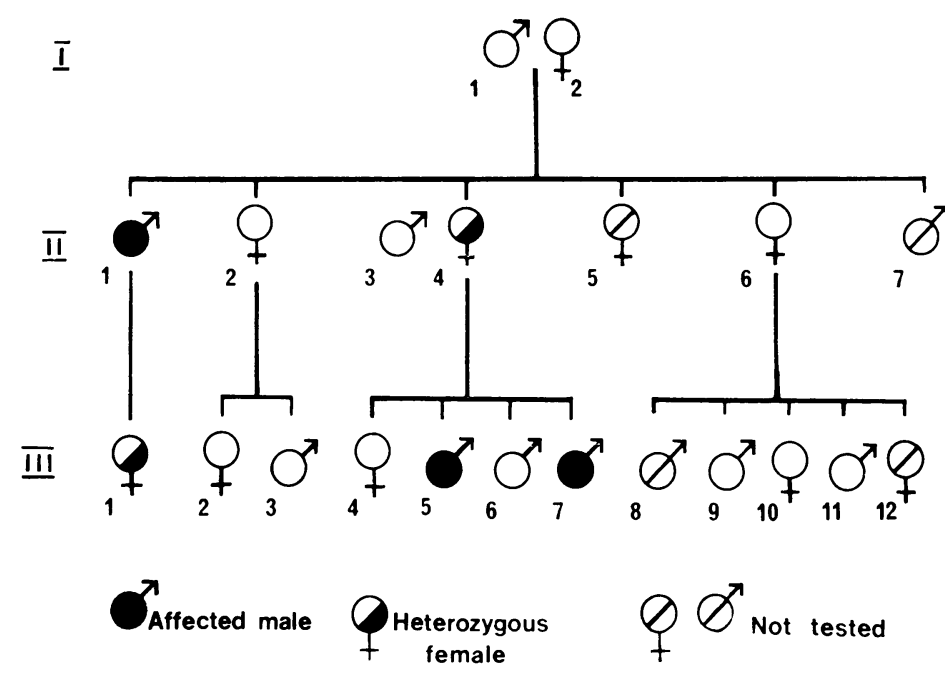

Fig. 1 Family tree.

normal differential, reticulocytes less than $1 \%$, platelets $200,000 / \mathrm{c} \mathrm{mm}$; a direct Coombs test gave a negative result, there was normal osmotic fragility; no cold agglutinins were detected, and the serum bilirubin was $1.5 \mathrm{mg} / 100 \mathrm{ml}$. The bone marrow showed intense normoblastic erythropoietic activity arrested at the intermediate normoblast stage; leucopoiesis and megakaryocyte activity were normal, as was starch gel electrophoresis of haemoglobin. Throat swabs grew commensal organisms and blood cultures were negative. Treatment with whole blood transfusion effected a dramatic improvement in the patient's condition, and he was discharged home 10 days after admission. Follow-up studies revealed slightly lowered haemoglobin levels $(10 \cdot 6-12 \cdot 4 \mathrm{~g} / 100 \mathrm{ml})$, a reticulocytosis $(8-12 \%)$, and raised serum bilirubin $(0 \cdot 7-1 \cdot 5 \mathrm{mg} / 100 \mathrm{ml})$. Three months after the initial investigations the red cell G6PD was found to be reduced.

The patient had had no previous episodes of jaundice, but at the age of 4 months, he had been admitted to hospital with bronchitis. Haemoglobin was found to be $8.6 \mathrm{~g} / 100 \mathrm{ml}$. No further investigations were carried out, though in retrospect this may have been the first manifestation of disease.

In January 1967 the patient had a haemolytic crisis, associated with a sore throat and penicillin therapy. Haemoglobin fell to $8 \cdot 3 \mathrm{~g} / 100 \mathrm{ml}$ with reticulocytosis up to $15 \%$. Since that time he has had four milder haemolytic episodes, usually associated with upper respiratory tract infections.

CASE III 7

A brother of the previous patient presented in June 1967, aged 5, with acute haemolytic anaemia. Abdominal pain, headache, and rigors $\cong$ began 24 hours before admission and he was noted to be pale and slightly yellow. He waso

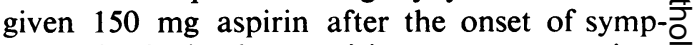
toms; he had taken aspirin on many previous occasions without ill effect. On examination $\overrightarrow{\vec{s}}$ he was febrile $\left(102^{\circ} \mathrm{F}\right)$, pale and slightly jaundiced: 0 The spleen was palpable, and laboratory in-등 vestigations showed the haemoglobin level to be $8.4 \mathrm{~g} / 100 \mathrm{ml}$, with packed cell volume $25 \%, \widetilde{\mathbb{\mathbb { Q }}}$ reticulocytes $13 \%$ rising to a maximum of $29 \%$ on the third day of admission, and bilirubin ${ }_{3}^{\infty}$ level $2 \cdot 2 \mathrm{mg} / 100 \mathrm{ml}$.

Because of a steadily falling haemoglobin, he $\overrightarrow{\vec{\omega}}$ was transfused with whole blood with satisfactory improvement. Subsequent follow-up studies con $=$ firmed a persistent reticulocytosis and elevatedi serum bilirubin levels, and three months afterw the initial investigations, the red cell G6PD was found to be reduced.

\section{Family Study}

The family tree is shown in Figure 1. One further case of chronic haemolytic anaemia was found; case II 1, a maternal uncle (aged 38) of the firsto patient (case III 5), who had never been jaundiceds or required blood transfusion.

This family study illustrates the features of chronic non-spherocytic haemolytic anaemia $\stackrel{\mathbb{Q}}{\mathscr{Q}}$ the rarest manifestation of G6PD deficiency. $\overrightarrow{\vec{\beta}}$ In three male members of the family, a com 3 pensated haemolytic state was demonstrated, In two children, there were crises of severeo anaemia, due usually to increased haemolysis but on one occasion (the first episode in case III 5) to inability of the marrow to compensate for the increased red cell breakdown.

The crises seemed commonly to be precipitated? by upper respiratory tract infection, and this is a feature of many reported cases (Shahidi and Diamond, 1959; Zinkham and Lenhard, 1959음 Kirkman and Riley, 1961). By contrast, drugs. are uncommon precipitating factors. Our second patient (case III 7) was given $150 \mathrm{mg}$ aspirin ${ }_{\mathrm{N}}$ although it appeared that haemolysis was already occurring at the time. In negroes, this dose would be insufficient to cause haemolysise (Beutler, 1959; Kellermeyer, Tarlov, Brewero Carson, and Alving, 1962), but in chroniळ haemolytic anaemia a smaller dose is likely to be required since G6PD levels are lower. In individual cases it is often difficult to decide whethe $\vec{D}$ haemolysis is precipitated by infection or by the drugs used for its treatment. Fikrig, Chun, and Watson (1966) reported a case in which sulpha\% furazole apparently caused haemolysis, but the drug was later given without ill effect. Boussero Christol, Boivin, Mallassenet, and Lods (1963항. described a haemolytic crisis precipitated b. aspirin but this was prescribed for a high fever. 


\begin{tabular}{|c|c|c|c|c|c|}
\hline \multicolumn{2}{|c|}{ Case No. } & \multirow{2}{*}{$\begin{array}{l}\begin{array}{l}\text { Haemoglobin } \\
(\mathrm{g} / 100 \mathrm{ml})\end{array} \\
16.0\end{array}$} & \multirow{2}{*}{$\begin{array}{l}\begin{array}{l}\text { Reticulocytes } \\
(\%)\end{array} \\
2\end{array}$} & \multirow{2}{*}{$\begin{array}{l}\begin{array}{l}\text { Bilirubin } \\
(\mathrm{mg} / 100 \mathrm{ml})\end{array} \\
-\end{array}$} & \multirow{2}{*}{$\begin{array}{l}\begin{array}{l}\text { Red Cell Half } \\
\text { Life (days) }\end{array} \\
-\end{array}$} \\
\hline I & 1 & & & & \\
\hline I & 2 & $14 \cdot 6$ & $\overline{2}$ & - & 一 \\
\hline II & 1 & $13 \cdot 1$ & 7 & 1.4 & $11 \cdot 5$ \\
\hline II & 2 & $15 \cdot 2$ & 2 & - & - \\
\hline II & 3 & $16 \cdot 6$ & 2 & - & - \\
\hline II & 4 & $12 \cdot 6$ & 5 & 0.6 & $28 \cdot 0$ \\
\hline II & 6 & 13.9 & - & - & - \\
\hline III & 1 & $12 \cdot 1$ & 2 & 0.5 & - \\
\hline III & 2 & $13 \cdot 6$ & 2 & - & - \\
\hline III & 3 & $16 \cdot 1$ & 2 & - & - \\
\hline III & 4 & $16 \cdot 1$ & 1 & - & - \\
\hline III & 5 & $13 \cdot 3$ & 16 & 1.6 & $7 \cdot 5$ \\
\hline III & 6 & 13.9 & 1 & - & - \\
\hline III & 7 & $11 \cdot 5$ & 13 & $2 \cdot 2$ & - \\
\hline III & 9 & $15 \cdot 2$ & 1 & - & - \\
\hline III & 10 & $11 \cdot 4$ & 1 & - & - \\
\hline III & 11 & $10 \cdot 8$ & - & - & - \\
\hline
\end{tabular}

Table I Haematological data

${ }^{1}$ Normal red cell half life $=28-32$ days.

\begin{tabular}{|c|c|c|c|c|c|}
\hline \multicolumn{2}{|c|}{ Case No. } & \multirow{2}{*}{$\begin{array}{l}\text { G6PD } \\
\text { (units/min/ml } \\
\text { packed red cells) }\end{array}$} & \multirow{2}{*}{$\begin{array}{l}\begin{array}{l}\text { Glutathione } \\
\text { Reductase } \\
\text { (units/min/ml } \\
\text { packed red cells) }\end{array} \\
1.05\end{array}$} & \multirow{2}{*}{ 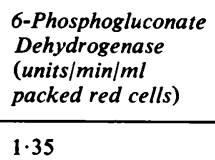 } & \multirow{2}{*}{$\begin{array}{l}\text { Reduced } \\
\text { Glutathione } \\
\text { (mg/lo0 ml } \\
\text { whole blood) }\end{array}$} \\
\hline I & & & & & \\
\hline I & 2 & $2 \cdot 70$ & 1.95 & 1.65 & - \\
\hline II & 1 & 0.45 & $1 \cdot 35$ & 2.55 & $11 \cdot 3$ \\
\hline II & 3 & $3 \cdot 37$ & 1.80 & $1 \cdot 50$ & $22 \cdot 5$ \\
\hline II & 4 & $2 \cdot 25$ & $1 \cdot 35$ & $2 \cdot 10$ & $24 \cdot 5$ \\
\hline II & 6 & $\mathbf{2} \cdot \mathbf{7 0}$ & $1 \cdot 20$ & 1.95 & $33 \cdot 4$ \\
\hline III & 1 & 2.85 & 0.90 & - & - \\
\hline III & 4 & 3.40 & 3.00 & 1.65 & $22 \cdot 0$ \\
\hline III & 5 & 0.15 & $3 \cdot 75$ & $2 \cdot 70$ & 1.6 \\
\hline III & 6 & $3 \cdot 30$ & $1 \cdot 20$ & 1.65 & - \\
\hline III & 7 & 0.90 & 1.65 & $2 \cdot 85$ & $13 \cdot 8$ \\
\hline III & 9 & $2 \cdot 50$ & - & - & - \\
\hline III & 10 & $2 \cdot 60$ & - & - & - \\
\hline III & 11 & 3.45 & $1 \cdot 65$ & $2 \cdot 10$ & $21 \cdot 3$ \\
\hline \multicolumn{2}{|c|}{$\begin{array}{l}\text { Normal } \\
\text { range }\end{array}$} & $\begin{array}{l}2.99 \pm 0.52 \\
\mathrm{n}=73\end{array}$ & $\begin{array}{l}1.66 \pm 0.51 \\
n=19\end{array}$ & $\begin{array}{l}1 \cdot 80 \pm 0 \cdot 29 \\
n=9\end{array}$ & $\begin{array}{l}23 \cdot 6 \pm 4 \cdot 0 \\
n=9\end{array}$ \\
\hline
\end{tabular}

Table II Enzyme data

${ }^{1} 1$ unit of enzyme activity is defined as a change of optical density of 1.0 at $340 \mathrm{~m} \mu$. G6PD estimations in cases II 2 , III 2 , and III 3 were carried out in a different laboratory; the results fell within the normal range for that laboratory.

Study of the family tree (Fig. 1) reveals three affected males, two brothers (III 5 and III 7) and their maternal uncle (II 1); these findings are consistent with the known sex-linked intermediate inheritance of the deficiency. In addition there are two obligatory heterozygotes. The mother (II 4) of the affected siblings (III 5 and III 7) had a slightly lowered G6PD level; reticulocytosis noted at the time of the study was probably due to menorrhagia, and red cell survival time was normal. The daughter (III 1) of the affected male (II 1) had a normal amount of G6PD. The observed variation in enzyme levels found in heterozygotes in this condition may be explained by $\mathrm{X}$ inactivation according to the Lyon hypothesis (Lyon, 1961).

Chronic haemolysis in these patients is presumably related to the constantly lowered levels of reduced glutathione: Jacob and Jandl (1962) showed that reduced glutathione has a protective action on the red cell surface, and G6PD is required for the maintenance of glutathione in the reduced state. A deficiency of G6PD is the end result of two possible situations, either a reduced rate of synthesis of a normal enzyme, or a normal rate of synthesis of an abnormal enzyme, either stable, but with low specific activity, or unstable. The clinical manifestations of the deficiency therefore depend upon the level of enzyme activity and the properties of the enzyme. There is evidence that another factor, possibly genetically determined, operates in families with favism (Stamatoyannopoulos, Fraser, Motulsky, Fessas, Akrivakis, and Papayannopoulou, 1966) and the discovery of a family with chronic haemolysis and G6PD mediterranean raises the possibility that other factors may operate in this condition (Beutler, Mathai, and Smith, 1968).

\section{Methods}

ENZYME ASSAYS

All enzyme assays were conducted at $25^{\circ} \mathrm{C}$. Glucose-6-phosphate dehydrogenase and 6-phosphogluconate dehydrogenase (6PGD) were assayed by the methods of Kornberg and Horecker (1955), and Horecker and Smyrniotis (1955). Glutathione reductase was assayed by the method of Racker (1955).

\section{GLUTATHIONE ESTIMATION}

Reduced glutathione was estimated by the method of Beutler (1957) and expressed as milligrams per 100 millilitres whole blood.

\section{PREPARATION OF HAEMOGLOBIN-FREE} EXTRACT

Ten $\mathrm{ml}$ red cells from a normal control and $25 \mathrm{ml}$ red cells from the G6PD-deficient patient II 1 were freed from haemoglobin by the method of Kirkman (1962). Modifications included the use of $1.0 \mathrm{mM}$ EDTA in all buffers and lysing solutions, and the use of DEAE-Sephadex A-50 instead of DEAE-cellulose in the batch technique. The haemoglobin-free A 50 eluate was concen- N trated to about $1 / 20$ of the original red cell $\sigma$ volume by vacuum dialysis against $50 \mathrm{mM}$

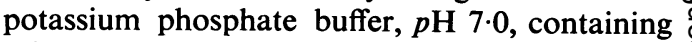
$1.0 \mathrm{mM}$ EDTA, $2 \mu \mathrm{M}$ NADP, $2 \mathrm{mM} \epsilon$-amino caproic acid, and $0.1 \% \mathrm{v} / \mathrm{v} \beta$-mercaptoethanol. These protective agents were also added to the eluate. Further purification by ammonium sulphate fractionation was unsuccessful, probably due to lability of the enzyme.

HORIZONTAL STARCH GEL ELECTROPHORESIS

This was carried out as by Fildes and Parr (1963). 
NADP, $0.5 \mathrm{mg}$ per cent $\mathrm{w} / \mathrm{v}$, was added to the gel before degassing and to the cathode vessel buffer. The gel was run at $4^{\circ} \mathrm{C}$ for 18 hours at 4.5 volts per $\mathrm{cm}$ of gel.

After slicing horizontally, one side of the gel was stained for G6PD and the other for 6PGD, both being visualized as purple bands of formazan at the site of enzyme action. Enzyme mobilities were expressed as percentages of the normal B type G6PD mobility which was taken as $100 \%$ on each run.

\section{MICHAELIS CONSTANT (KM) FOR GLUCOSE PHOSPHATE}

The following assay conditions were used: 0.05 $\mathrm{M}$ Tris- $\mathrm{HCl}$ buffer, $p \mathrm{H} \mathrm{7.6,0.016} \mathrm{M}$ magnesium chloride, $0 \cdot 1 \mathrm{mM}$ NADP, $0 \cdot 25-0 \cdot 0625 \mathrm{mM}$ glucose6-phosphate, and enzyme extract, $0.5 \mathrm{ml}$ from patient II 1, and $0.05 \mathrm{ml}$ from a control patient. The $\mathrm{Km}$ for glucose-6-phosphate was calculated from the negative intercept on the $1 / \mathrm{S}$ axis of the Lineweaver-Burke plot.

Other haematological studies were performed using the methods of Dacie and Lewis (1963).

\section{Results}

The results of haematological studies, enzyme assays, and glutathione estimations are shown in Tables I and II. The determinations on affected members of the family were carried out in the chronic phase, at the same time as the determinations on the other members of the family, and at least three months after the last haemolytic episode or blood transfusion.

The result of starch gel electrophoresis is shown in Figure 2. In the patient's extract, the G6PD shows $71 \%$ of the normal mobility of the B variant. Dilution of the normal extract to the level of activity in the deficient extract did not alter the enzyme mobility. No G6PD band could be seen in the patient's whole haemolysate. In a normal whole haemolysate, the G6PD band appears at the same position as in the normal partially purified extract.

In a normal whole haemolysate, and in both normal and G6PD-deficient extracts, the 6phosphogluconate dehydrogenase shows $58 \%$ of the normal G6PD mobility. This is considerably slower than the variant G6PD described here.

Under the stated conditions the normal G6PD had a $\mathrm{Km}$ for glucose-6-phosphate of $37 \mu$ molar, while that of the enzyme from the deficient subject II 1 was $123 \mu$ molar, showing a threefold increase. However, these results cannot be taken as conclusive proof of a lowered affinity of abnormal enzyme towards glucose-6phosphate, owing to the contamination of

\section{Discussion}

A number of enzyme variants have be characterized in patients with chronic haemolys and G6PD deficiency. Beutler et al (1968 reviewed nine variants occurring in populations of western european origin, and Wong, Shi and Hsia (1965) described two found among th Chinese. The present studies show that the disease in our cases is associated with an enzyme variag with a very slow electrophoretic mobility. which appears to differ significantly from thos previously described. We suggest that this variant should be referred to as 'G6PD Fulham' i accordance with the recommendations of thes World Health Organization (1967).

We wish to thank Dr L. J. Grant and Dr L. Sincla i for permission to study patients under their care Dr E. R. Huehns for considerable help in the prefaration of this paper, Dr C. W. Parr for the whice cell studies, Dr J. G. Humble for advice on the manuscript, the Westminster Hospital Photographic Department for the illustrations, and members of the Haematology and Biochemistry departments of St. Stephen's Hospital for much practical assistanco.

References

Beutler, E. (1957). The glutathione instability of drug-sensiture red cells. J. Lab. clin. Med., 49, 84-95.

Beutler, E. (1959). The hemolytic effect of primaquine and relaten compounds: a review. Blood, 14, 103-139. 
Beutler, E., Mathai, C. K., and Smith, J. E. (1968). Biochemical variants of glucose-6-phosphate dehydrogenase giving rise to congenital nonspherocytic hemolytic disease. Blood, $31,131-150$.

Blackburn, E. K., and Lorber, J. (1963). Chronic haemolytic anaemia due to glucose-6-phosphate dehydrogenase deficiency. Proc. roy. Soc. Med., 56, 505.

Bousser, J., Christol, D., Boivin, P., Mallassenet, R., and Lods, J. C. (1963). Ictère hémolytique congénital non sphérocytaire avec déficit en glucose-6-phosphate déhydrogénase. Deux observations. Nouv. Rev. franc. Hémat., 3, 505-511.

Bowdler, A. J., and Prankerd, T. A. J. (1964). Studies in congenital non-sphèrocytic haemolytic anaemias with specific enzyme defects. Acta haemat. (Basel), 31, 65-78.

Brodribb, H. S., and Worssam, A. R. H. (1961). Favism in an Englishwoman. Brit. med.J., 1, 1367-1368.

Carson, P. E., and Frischer, H. (1966). Glucose-6-phosphate dehydrogenase deficiency and related disorders of the pentose phosphate pathway. Amer. J. Med., 41, 744-761.

Dacie, J. V., and Lewis, S. M. (1963). Practical Haematology, 3rd ed. Churchill, London.

Davies, P. (1962). Favism: a family study. Quart. J. Med., 31, $157-175$.

Fikrig, S., Chun, T., and Watson, J. (1966). Relationship between erythrocyte glucose-6-phosphate dehydrogenase and the hemolytic anemia of infection. Pediatrics, 38, 291-293.

Fildes, R. A., and Parr, C. W. (1963). Human red-cell phosphogluconate dehydrogenase. Nature (Lond.), 200, 890-891.

Horecker, B. L., and Smyrniotis, P.Z.(1955). In Methods in Enzymology, edited by S. P. Colowick and N. O. Kaplan, vol. I, p. 323. Academic Press, New York and London.

Jacob, H. S., and Jandl, J. H. (1962). Effects of sulf hydryl inhibition on red blood cells. I. Mechanism of hemolysis. J.clin. Invest., 41, 779-792.
Kellermeyer, R. W., Tarlov, A. R., Brewer, G. J., Carson, P. E., and Alving, A. S. (1962). Hemolytic effect of therapeutic drugs. J. Amer. med. Ass., 180, 388-394.

Kirkman, H. N., and Riley, H. D., Congenital non-spherocytic haemolytic anaemia. Amer. J. Dis. Childh., 102, 313-320.

Kirkman, H. N. (1962). Glucose 6-phosphate dehydrogenase from human erythrocytes. J. biol. Chem., 237, 2364-2370.

Kornberg, A., and Horecker, B. L. (1955). In Methods in Enzymology, edited by S. P. Colowick and N. O. Kaplan, vol. I, p. 323. Academic Press, New York and London.

Lyon, M. F. (1961). Gene action in the x-chromosome of the mouse. Nature (Lond.), 190, 372-373.

Racker, E. (1955). In Methods in Enzymology, edited by S. P. Colowick and N. O. Kaplan, vol. II, p. 722. Academic Press, New York and London.

Shahidi, N. T., and Diamond, L. K. (1959). Enzyme deficiency in erythrocytes in congenital nonspherocytic hemolytic anemia. Pediatrics, 24, 245-253.

Stamatoyannopoulos, G., Fraser, G. R., Motulsky, A. G., Fessas, P., Akrivakis, A., and Papayannopoulou, T. (1966). On the familial predisposition to favism. Amer. $J$. hum. Genet., 18, 253-263.

Wong, P. W. K., Shih, L. Y., and Hsia, D. Y. Y. (1965). Characterization of glucose-6-phosphate dehydrogenase among Chinese. Nature (Lond.), 208, 1323-1324.

World Health Organization (1967). Standardization of procedures for the study of glucose-6-phosphate dehydrogenase. Wld Hlth Org. techn. Rep. Ser., 366.

Zinkham, W. H., and Lenhard, R. E., Jr. (1959). Observations on the significance of primaquine-sensitive erythrocytes in patients with congenital nonspherocytic hemolytic anemia. Amer.J. Dis. Childh., 98, 443. 